\title{
From a Japanese Notebook: Afro-Asian Critical Cosmopolitanisms in William Demby's 1950s Reportage from Postwar Japan
}

In early November of 1953, the African American author William Demby sent a postcard to Rome from Calcutta to his new bride, Italian writer Lucia Drudi. The postcard bears a black and white photograph captioned, "Lake, Calcutta," which is superimposed with a blue ink stamp reading, "Pan American World Airways Inc." On the back is a brief note: "Tomorrow we arrive at Hong Kong." $" 58$ Demby would spend a total of three months in Japan with a film crew. In a letter typed on blue parchment and sent from Tokyo a week later, Demby confides to his wife that he is disappointed with the film project. He mentions a lackluster press conference, before affirming his goal to work on a book project about Japan, particularly now that his typewriter has arrived. Sounding his critical distance from the United States and aversion to the projection of Americanism abroad through military occupation and cultural exports, he concludes: "[Tokio] [sic] is repulsive, it being so expensive and vulgar and filled with American soldiers and Japanese imitating Americans.”

At the time of this trip to Asia, Demby had been living in Rome for six years, since 1947, following his service in Italy during World War II. Though Demby also traveled on journalistic assignments to postcolonial Ethiopia, much of Europe, and the United States South in the 1950s, this chapter focuses on his 1953 trip to Japan to position Demby as a critical cosmopolitan thinker and practitioner, whose transnational, multimedia work in fiction, journalism, and cinema marks an under-considered contribution to the projects of decolonization and social liberation. Demby's genrebending writings are in keeping with David Hollinger's claim that "cosmopolitanism urges each individual and collective unit to absorb as much varied experience as it can, while retaining its capacity to advance its aims effectively" (84). Demby's critical cosmopolitanism is one marked by overlapping and competing socio-political forces, writing as he was in the 1950s and 1960s from post-fascist Italy in the aftermath of the Holocaust and World War II, in which he participated in a segregated army, and amid decolonization.

Demby's experiences in Japan resulted in a slim, self-reflexive book, which he submitted to his New York agent, Martha Winston, not long after his trip but which never found a publisher. The book, alternately titled in Demby's papers as Geisha

58 This correspondence is quoted from the William Demby Papers, housed at the Villa Podernovo, in Tuscany, Italy, with the permission of Demby's son and literary executor, James Demby. All subsequent references to this private collection, which I inventoried in 2014, will be cited as the William Demby Papers. 
and From a Japanese Notebook, is a collection of some fifteen profile pieces describing Japanese cultural and religious practices, including the Noh theater; Kabuki; the children's parade of Shichi-Go-San; Buddhism; and the art of bonsai. Demby inserts himself into each vignette, often using the first-person to make his observations and sometimes self-reflexively calling himself a "foreigner" ("Geisha Girls" 41). More often than not, his profiles describe moments of misunderstanding and misinterpretation. For instance, in "Nakiri," a profile of Japanese women pearl divers, he follows the foiled attempts of the film crew with whom he is traveling to find a beautiful diver among the women to "star" in the movie. The woman they choose from a neighboring village turns out to be pregnant and gets sick out on the boat. Demby's book, with its insistent distance from and attention to mediated forms of interaction, is distinct from, even if not entirely outside of, Orientalist ethnographies and Western travel writing about Japan; ${ }^{59}$ with its subtle emphasis on ways of (mis)reading the world, the book refuses claims to mastery, dwelling instead in moments of indeterminacy.

Demby captures glimpses or "snapshots" in Japan of what Bhabha has termed "spectral sovereignty," whereby the nation-state inheres, even in a "tattered" form (142) - in the case of Japan, in defeat and under United States occupation-an indeterminate site from which a negative politics of ontology might emerge to enact "political practices and ethical choices" that exceed ethno-racial categorizations or fixed “identities" (146). Compellingly, alongside Japanese cultural profiles, Demby's book accounts for Japanese traditions being adopted and adapted from Chinese culture; the presence of international expatriates in Japan; international religious students; the presence of translators and guides; and so on, thereby showcasing cosmopolitanism as a set of acts, which may be communal, and as a mode of tacit and explicit knowledges being exchanged, interpreted, or contemplated. Demby's critical project in From a Japanese Notebook is in keeping with Hollinger's characterization that "cosmopolitanism is more wary of traditional enclosures and favors voluntary affiliations. Cosmopolitanism promotes multiple identities, emphasizes the dynamic and changing character of many groups, and is responsive to the potential for creating new cultural combinations" (3).

Demby's book remained in manuscript form at the time of the author's death, tucked away in an armoire among his papers from his decades spent working as a writer in Rome. Though the project was never released in book form, several excerpts were published in periodicals in the 1950s, including Harper's, Epoca, an Italian-language magazine, and the multi-lingual literary journal Botteghe Oscure, published in Rome with niche global distribution. Such publication histories and these articles'

59 In Orientalism, Edward Said surveys a vast body of writing in the period of so-called high modernism that figures the East as the object of the West's consuming gaze. Traise Yamamoto points out the gendering function of this gaze, which feminized the East and constructed Japan, in particular, "in terms of absolute alterity" (13). 
critical insights register the circulation of Demby's cosmopolitan reportage in Cold War print culture. In the contexts of twenty-first-century scholarship on the plurality of cosmopolitanisms and on the depth of Afro-Asian solidarities as resistance to colonial and imperial systems of oppression, Demby's 1950s writings on Japan and their Cold War circulation merit our critical attention for their complex negotiation of competing and often contradictory allegiances, as well as their political and psychic sites of issuance.

“The Traveller," the opening, unpublished chapter of Demby's From a Japanese Notebook, self-reflexively presents the idea of "Japan" as a Western, Orientalist construct. Demby presents a critical engagement with this "Japan" formed in his childhood and adolescence, spent primarily in a white immigrant neighborhood in Pittsburgh, Pennsylvania. Notably, the book opens in a first-person register, immediately dispensing with objectivity, and then calls the reader's attention to the circulation of anti-Japanese World War II propaganda. Demby recalls, for instance, being asked as a high school sophomore to paste "political cartoons in [his] scrap book out of the editorial pages of newspapers and magazines-caricatures of Japanese war lords grinning deceitfully like diabolic monkeys" (1-2). Layering autobiographical meditation and mediation into his own reportage signals his use of New Journalism strategies of the 1960s and 1970s avant la lettre and, at the same time, ushers into the text the presence of cultural biases and indoctrinating wartime discourses of "us" versus "them"-so crucial to the shoring up of national identity and belonging. The limits of this formulation of an "American us," of course, is laid bare in the state-sanctioned segregation of the United States population and its armed forces.

"The Traveller" significantly defamiliarizes the tropes of membership and belonging aligned with nationalism and presents African American experience as heterogeneous as Demby traces his family's move from urban North to rural South in the context of his own coming of age. After Demby's family moves from Pittsburgh to Clarksburg, West Virginia, he makes the conscious choice to enroll at West Virginia State College, a historically black college, amid the outbreak of world war, marking his first immersion in a broader African American community. He recalls listening "shyly, though secretly thrilled," "in the barbershop, in the shower-room, and on the steps of the campus church," as black students from Mississippi and Alabama "talked passionately about the 'Japs' and how they were going to teach white folks a lesson they would never forget” (2). Demby sets off "Japs," a pervasive racial epithet of the period, in quotation marks, estranging its use by African Americans who look to Japan in a manner that contrasts with the majority of white US citizens (the latter emblematized by his high school scrapbook assignment): as a legitimate rival to North American and European powers. After leaving college to train for the war, Demby was deployed to Italy, where his segregated troop worked as supply truck drivers-experiences Demby draws on in his final novel, King Comus (2017), which I discuss later in this chapter. 
In “The Traveller,” Demby recalls being in Italy during the war, where his troop was:

camped in a fragrant wheat field in the Po Valley north of Bologna when one morning the news came that an atom bomb had been dropped. Almost for the first time since those days back in college I began to think of Japan as a land where real people lived; and I took my breakfast to the far side of the camp and sat on the running board of a truck, the strange word 'Hiroshima' running through my head. (3)

Such recollections operate as the book's opening frame and commingle with Demby's postwar writings from Japan, signaling his awareness of the (de)construction of otherness. Demby maps a journey across time and space: from his immersion in racist wartime rhetoric in Pittsburgh; to his exposure in Clarksburg to a critique of white supremacy and the prospect of transracial solidarity with Japan; to his attempts to process in the Italian countryside the meaning and effects of the ultimate act of war waged against Japan, “a land where real people lived.” In “Traveller,” Demby self-consciously narrates his emerging understandings of an interconnected world brought about by global warfare and writ large against a backdrop of violence, turmoil, and the Holocaust.

Demby's creative cohort in Rome illustrates the complexity of cosmopolitan perspectives forming in the wake of Italo-facism and World War II. In Rome, Demby lived in an artists' commune in the late 1940s and early 1950s among Italian Communist artists and filmmakers who were admirers of Antonio Gramsci's writings, including Renzo Vespignani and Marcello Muccini (Demby, “An American” II-1). Among this cohort were US expatriates, including journalist Bill Pepper and writer Alex Randolph, who had served in the Office of Strategic Services (OSS) and Army intelligence during the war. These strange bedfellows, nevertheless, contributed to the immediacy of an anti-fascist response to Italy's wartime zealotry and violence, including state collusion with the Nazis and the expulsion of Italian Jews to death camps. Demby recalls of the postwar years in Rome: "There was a cult of the left that everyone wanted to embrace; you wouldn't see anyone trying to be a fascist, or coming around and dressing in a black shirt" (Micconi 127). These complex socio-political forces drive Demby's postwar writings across media, and must be thought of alongside and in relation to the competing agendas of Cold War geopolitics marked by US hegemony and the era's social liberation movements.

Demby's exilic perspectives from Rome are woven into his writings for transnational culture industries, namely periodicals and the Italian cinema. In Rome's revolutionary postwar milieu, he completed his first novel, Beetlecreek (1950), which traces fascist thinking and ensuing racial violence in a small town in the United States South during the Depression era. The novel was well-received and released 
simultaneously in English by Rinehart and in Italian by Mondadori. ${ }^{60}$ Mondadori sent Demby on assignment to Ethiopia in 1950 to interview Emperor Haile Selassie for their new glossy magazine, Epoca. Demby's multi-article reportage describes the nation's vibrancy as well as its rebuilding in the wake of Italian colonization. Alongside his work as a journalist, Demby became known in the 1950s as a fast and effective translator of Italian-language scripts into idiomatic English, forging friendships and creative alliances with several leftist filmmakers, including Roberto Rossellini and Federico Fellini. In turn, Demby's critical cosmopolitanism is the product of multiple socio-cultural and political forces: his having moved from the United States North to the South, from a predominantly white neighborhood into a segregated African American community; his service in a segregated troop; his living in war-torn Italy and marriage to an Italian writer; his postwar travels and work in the culture industries, which sent him on assignment to a range of countries; and his exilic distance from the United States.

Among Demby's papers from the 1950s is a letter from Hungarian photographer Francis Haar, who presents another model of cosmopolitanism in practice. Demby met Haar in Japan-he is likely “H.” in Demby's From a Japanese Notebook. Haar came of age in Budapest, among an experimental group of leftist artists, the "Munka Kor," or the "Work Circle"; he first visited Japan in 1939 and went on to open a studio in Tokyo in the early 1940s, which he ran until the mid-1950s before settling in Hawaii (Haar 4). In February of 1954, upon Demby's return to Rome from Japan, Haar wrote to him on Film Tokyo Corporation stationary, describing the possibility of their doing a film together, with Haar directing and Demby writing a scenario: "perhaps based on Noh stories, or the story of the Fisher man with the Angel 'Hagoromo,' " or the "other fisher boy who visits the land of the Sea King and marry [sic] his daughter." Haar describes his appreciation for Demby's "open mind for new experiences and not limited by short-sighted, fix [sic] ideas as most of the foreigners visiting Japan.” He wonders, "How far did you get with your book about Japan? It will certainly become a very interesting and successful book." Haar's appreciation for his new friend revolves around notions of cosmopolitanism, which Haar defines in opposition to the "shortsighted, fix [ed] ideas" that "most of the foreigners visiting Japan" hold. Demby-living in Cold War Italy, a defeated nation rebuilding itself from the intellectual and physical ruins of fascism, and traveling through Japan, itself a former Axis and imperial power grappling with defeat-was poised to articulate a complex global landscape in his reportage, one undoubtedly influenced by projections of Americanism abroad, in cultural and militaristic forms.

Operating as critical cosmopolitanism in practice, Demby's postwar writings weave together elements of narrative journalism, life writing, and documentary

60 In 1961, Beetlecreek was published in Japanese by the Charles Tuttle Company in Tokyo, translated by Soichi Minakawa. 
realism. Demby, like fellow black diasporic writers, including Frantz Fanon, W.E.B. Du Bois, Richard Wright, and Maya Angelou, brought cosmopolitan viewpoints to his nonfiction writing, often by wedding observations of a world in flux to lived experience and traveling to and residing in diverse locales; like his contemporaries, Demby weaves elements of life writing into his reportage, situating himself within the text and rejecting the Enlightenment posture of the objective onlooker. This work gives voice to an embodied subject position that moves through the world with a heightened awareness of the social forces that collectively produce social identity, often with oppressive effects.

\section{Demby's Critical Cosmopolitan Writings About Japan in Cold War Print Culture}

Following his journalistic pieces on postcolonial Ethiopia, Demby continued publishing Italian-language articles in Epoca through the 1950s on topics ranging from the "Gypsies of Abruzzo" to an account of "John Steinbeck in Rome." ${ }^{\text {"In }}$ In Epoca's June 1954 issue, Demby published his first piece from his Japan project, "The Priesthood of Illusion," about the training, customs, and practices of the geishas, listed among the magazine's articles about "The World Today” and with photographs credited to Demby. In Epoca's August 1954 issue, as the sole article listed under "The Theater," Demby published “They Laugh and Cry Under the Mask," about the Noh theater. In October 1954, under “The World Today," Epoca published Demby's "The Signs of Mr. Mikimoto," which details the routines and skill of Japanese women pearl divers, with photographs credited to Demby.

It was not until December 1954, nearly a year after his trip to Japan, that Demby placed his English-language article, “The Geisha Girls of Ponto-cho,” in Harper's. Signaling the magazine's mainstream readership, "The Geisha Girls of Ponto-cho" was published in an issue that included such eclectic pieces as "Do I Have to Give Up Smoking?" (25-30), and "What a Secretary of State Really Does," penned by former Secretary of State to Truman, Dean Acheson (48). Demby's article profiles the geisha women of the Ponto-cho district of Kyoto. The article rests its attention on the communal life of the geishas and their ability, in Demby's estimation, to render powerful men silly and childlike in the course of their ritualistic performances. The article ends on a cautionary note: "I think to myself: Yes, you are a monster. But I know that she is also a goddess, in whose company it is inspiring to bask-for a short time. But

61 Steinbeck's Italian interests were represented by a literary agency in Rome run by Demby's wife, Lucia Drudi Demby, and her sister, Gabriela Drudi. 
woe to the man who considers her an ordinary mortal woman and lingers too long at her side" ("Geisha Girls" 47). The piece ascribes power and control to the geishas, who are said to indulge the male gaze, only to thwart its will to mastery, exposing it as an illusion. Reminiscent of what James Clifford terms a "cosmopolitanism from below" (qtd. in Robbins and Horta 9) - that is, of Japanese women, many from rural areas, being trained to entertain successful Japanese and international clients-the piece ascribes power to these women by virtue of their ability to read a room and respond accordingly.

In spite of his having published several articles from the book project, in January of 1955, Demby received word from his agent, Martha Winston, that Rinehart was passing on his collection. They offered this feedback: "We admit that there is interest on the Orient, but feel that this book is so personal and so much a group of little vignettes, that we think it would be hard to find a market for it." This rejection on the grounds of the text being too "personal" speaks to the avant-garde daring of Demby's nonfiction: that is, his reportage's blending of narrative and autobiographical techniques with his expository prose-features, again, that would become commonplace in the New Journalism. Winston, ever a champion of Demby's work, sent his manuscript on to other publishers, which did not, however, bear any fruit. ${ }^{62}$ Here, the text lay in wait for several years, but, in the end, it never found a publisher.

A considerable excerpt, titled "From a Japanese Notebook," was published some three years later in 1959 in the transnational literary journal Botteghe Oscure. The publication is notable, given the journal's commitment to publishing a world literature in the aftermath of World War II. Botteghe Oscure was founded in Rome in 1948 by US expatriate Marguerite Caetani, a New Englander who, upon marrying Roffredo Caetani, an Italian duke, became Princess Caetani. Botteghe Oscure was Caetani's second major literary journal-the first being Commerce, a literary review founded in Paris and published in French, which ran from 1924-32. ${ }^{63}$ Published from Rome, Botteghe Oscure ran for twenty-five volumes, before closing its pages in 1960. Envisioning itself as a global publication, it "appeared in Italian, French, German, Spanish, English, and American," and its niche distribution reached locales including "Tokyo,

62 Winston sent the book to Bill Raney at Dutton and, in June of 1956, a year and a half after Rinehart's rejection, she wrote that she could not "clinch anything with Secker and Warburg [a British press]" unless Demby could give her "some idea of what the added chapters will cover." The following month, on July 25, 1956, Winston wrote from New York, "Scribner found impressive quality in GEISHA. They thought the pieces perceptive and graceful but as a book, shapeless. They want to go on record as interested in your work." She advised Demby to complete a revision with new material so that Scribner could have a second look, along with Secker and Warburg.

63 Signaling the international direction that Botteghe Oscure would take, Commerce published sections of Joyce's Ulysses, Faulkner's "A Rose for Emily," poems from T. S. Eliot, including "The Hollow Men," as well as work by Virginia Woolf, André Breton, Emilio Cecchi, Cheng-Tscheng, André Gide, André Malreaux, Edith Sitwell, and Rainer Maria Rilke. 
Amsterdam, Wiesbaden, London, Paris, Melbourne, Johannesburg, and Middletown, Connecticut"; a 1960 indexing of the journal calculated that its writers "numbered more than 650 of thirty-odd nationalities" (MacLeish ix). Against the Pax Americana's solidification of power, writers from some "thirty-odd nationalities" were given a voice with global circulation.

In 1960, writer Archibald MacLeish observes in an essay about Botteghe Oscure that, although the circulation of the periodical never surpassed "much over five thousand," its writers included such visionaries as: "Brecht and Camus and Auden and Char and Moravia and Silone and Agee and Robert Penn Warren and Dylan Thomas, ... most of them too young to be widely known" (ix). Of the journal's achievement, he observes that "at any period in the world's history, a magazine dedicated so visibly to the proposition that literature exists in a wider and more integral world than politics would have attracted attention" (ix). This cosmopolitan plea for a view made possible by literature of "a wider and more integral world," nevertheless, collides with the Cold War-period's geopolitics and modernist culture's peculiar cooptation by the United States nation-state (Saunders 1). To that end, MacLeish laments, "In a time as frantically nationalistic as ours, such a magazine becomes a prodigy and an anachronism" (ix-x), owing to "an era in which political pressures continued to be applied even in the United States to make patriotism and art coterminous if not identical" (x). The characterization of Botteghe Oscure as a "prodigy and an anachronism" is a testament to a cosmopolitan vision predicated on heterogeneity and compilation, rather than synthesis.

MacLeish lauds Marguerite Caetani’s achievement: "In an ignorant, nationalistic, and fanatical time, paralyzed by public hatreds, she kept a small flow of international literature alive and gave hundreds of young writers, in the loneliness of their defeated work, the hope that they too might become a generation-perhaps the first of all the literary generations to inherit the wholeness of the world" (MacLeish xii). MacLeish's cosmopolitan assessment, again, penned at the apex of the Cold War, rebukes nationalism as partner to ignorance and fanaticism and privileges the global as the writer's true creative inheritance. Critiques of cosmopolitanism have aptly pointed out that open access to travel and border-crossing are available to a select few, while, in many cases, migration is forced upon those seeking refuge and asylum, thus pointing to an inherent elitism and asymmetry built into the notion of cosmopolitanism (Bhabha 144; Horta 153). MacLeish, though, makes a particular space here for cosmopolitan writers who seek expressive communion with the world; artists, in other words, are an exceptional cosmopolitan group who engage in figurative and literal wandering and ever-expanding experiences of being.

William Demby was a writer who aimed to embrace the world beyond the nation in his writings and it is fitting, in many ways, that it was in Botteghe Oscure that the most extended excerpt of his writings on Japan appeared. The English-language excerpt "From a Japanese Notebook" was published in a typically eclectic issue, including poems in Italian from Bernardo Bertolucci, for instance, and in English 
from Robert Penn Warren. Demby’s “From a Japanese Notebook” includes four sections from his book: "Nakiri," about the Japanese women pearl divers; "Shichi-GoSan," which details a children's parade and celebratory feast at the Meiji Shrine; "The Buddha From Chicago," about a US citizen studying Buddhism, with plans to serve as a missionary back home in Chicago but whose heart lies with a Japanese woman whose father will not countenance their interracial love; and "Bonsai," a profile of the cultural practice, which ends with Demby's failed attempt to tend a bonsai tree back home in Rome. "Nakiri" and "Bonsai," in particular, demonstrate the slippage between preconceived expectations and actual cross-cultural encounters, highlighting the problematics of both consuming and producing culture.

"Bonsai," the final section published in Botteghe Oscure, metaphorizes Demby's practice of critical cosmopolitanisms. He offers an overview of bonsai as an ancient art form from China but transformed over time in Japan. Demby claims these trees are to be found in every Japanese home, irrespective of class, and are representative of the "Japanese soul" ("From a Japanese Notebook" 264). In explaining the concept of sabi, he describes the care taken to cultivate the tree's branches: not "striving toward the sky with insatiable ambition," but instead they "should evidence a kind of philosophic humility" (264). He admires those Japanese gardeners who have mastered this "forbidding and all-consuming art, one that requires patience, genius, and, above all, compassion" (266). Demby's tone of veneration implicitly opposes a Western capitalistic ethos of efficiency against the virtues of a prolonged, meditative ritual that forms horizontal affiliations across class lines in Japan.

Demby casts himself as a consumer of culture and indicates the impossibility of an outsider fully comprehending the nuances of this cultural practice by the chapter's (and book's) end. Visiting a bonsai market in Tokyo, Demby and his friend take in the particular beauty of the trees for over an hour before selecting one to take home. Demby spots "a plum tree with twin trunks and sensuous knotted branches that seemed to reach out and embrace itself like the old man and his wife in the legend who meet again after death"; as soon as he spots it, he is "filled with a fever of possession" ("From a Japanese Notebook" 267). The tree is sixty years old and has been cared for by its sixty-five-year-old gardener since he was a child. Demby convinces his companion to buy it, as the price is out of his reach, but to let him host it in his hotel room during his final days in Tokyo (267). Demby, however, becomes increasingly attached to the tree and decides he cannot leave it behind; he takes it with him aboard several planes en route to Italy:

I made a nuisance of myself with the airplane hostess by insisting that the tree occupy the seat next to mine; I stared down suspicious custom officials in five countries; I accepted the admiring smiles of homesick Japanese nationals in Siam with fatherly condescension; and in the hellish tropical heat of Bankok [sic], when the tree seemed to wilt, I covered it with a dampened towel. (267) 
In Italy, the tree at first seems to thrive in the mild Roman spring, but then larvae appear, "spreading a malignant web over the branches, selecting the most tender undefended buds to feed on" (267). Demby has a "premonition of the end and recognize[s his] guilt" (267), recalling the advice he had heard from friends in Tokyo: "Such a tree cannot endure away from the loving care of its creator" (268). The last sentence of the "Bonsai" is a lament: "What was once the embrace of ghostly lovers has become the clutching of skeletons, macabre in their grappling with death" (268).

"Bonsai" presents an encounter with and an homage to aesthetic beauty across cultural and national boundaries. Demby takes care, however, to delineate an unbreachable gap as he reflexively ponders his own impossible desire for "possession." As Paulo Lemos Horta posits, "Cosmopolitanism in its most vigorous form should entail a willingness to be transformed by an experience of the foreign" (153). Demby's personal desire is, at the same time, a public one. The fever of possession conjures a colonial, imperial impulse to take hold of and claim the other as one's own-so often couched in the language of benevolence and paternalism. Demby's months in Japan come to a close in the bitter chill of winter, and one cannot ignore the presence of Cold War geopolitics and nuclear anxiety. In this way, "Bonsai," the last vignette in Demby's book project, remains open to an allegorical interpretation of conquest and devastation wrought by warring powers-one in decline and another in ascent. The two skeletons entwined at the close of the piece, ghostly lovers who "meet again after death" (267), connote an image of nuclear holocaust, made real in the aftermath of Hiroshima and Nagasaki.

Notably, the 1959 publication of this excerpt from From a Japanese Notebook in Cold War print culture coincides with Demby's active attempts to innovate his novelistic practice, by gathering newspaper clippings and beginning a thought experiment that would culminate in his most well-known novel, The Catacombs (1965). His novel juxtaposes textual collages from the daily news of 1962-64, alongside filmic dialogues that are imbedded in a novel within the novel. Ewa Luczak notes in her treatment of The Catacombs that Demby is working from a global perspective that resonates with Léopold Senghor's theorization of négritude at the Second World Congress of Negro Writers, held in Rome in 1959, calling for a new political, cultural, and ideological order (114-15; 118). Having worked consistently as a journalist and in the Italian cinema through the 1950s and into the 1960s, Demby's second novel bears the imprint of transnational media forms. Critical cosmopolitanisms, in these manifestations, are a response to time and place as multiple and dynamic and to artistic forms as open to hybridization and transmediality. 


\section{Afro-Asian Solidarities: Retrospective Historiography in King Comus (2017)}

Two years after Demby's transformative sojourn to Japan, the historic Afro-Asian Bandung Conference was held in Java in 1955. In 1956, Demby stopped off in Paris on his way back home to Rome from the United States, where he had traveled through the South on assignment for Reporter magazine, profiling the Montgomery bus boycott. In Paris, he visited with Richard Wright in the author's apartment. The two discussed the Bandung Conference and Wright's The Color Curtain, which he wrote in response to the experience and would publish that fall. In its opening section, Wright describes learning of the conference in a newspaper announcement that described a meeting to discuss "racialism and colonialism" involving twenty-nine nations. Wright's account, delivered in the mode of life writing, enumerates the explosion of ideas that this announcement precipitated: He calculates, for example, the populations of the countries involved-amounting to over "a billion colored people"-and ponders the fact that many of these nations were now led by men who had been political prisoners, or lived in exile. "In short," he declares, "the underdogs of the human race were meeting" to discuss forces "beyond left and right," that is, race and religion (12). The critical cosmopolitan energies that converged at the Bandung Conference marked a decisive move toward a global liberationist politics predicated upon the world's majority population of color organizing against sustained systems of oppression and adopting decolonizing strategies, both material and psychic.

Scholars Nahum Chandler, Bill Mullen, Gerald Horne, and Yuichiro Onishi, among others, have observed that for many African American writers and intellectuals-including, perhaps most prominently, W.E.B. Du Bois and Paul Robeson-Japan was long a site of inspiration and fascination in relation to the black freedom struggle, as it demonstrated that modernity and modernization were not particular to European societies. For Du Bois, writing in 1900, “Japan [was] 'the one bright spot' in all of Asia, as an ongoing challenge to the European and American promulgation of a 'color line' " (qtd. in Chandler 292). Gerald Horne's critical study Facing the Rising Sun: African Americans, Japan, and the Rise of Afro-Asian Solidarity (2018) opens with an anecdote in which Malcolm X, then Malcolm Little, tells an army psychiatrist that he is "frantic to join" the Japanese forces. Horne notes that "his dissembling had to be taken seriously," as "in preceding years Japan had made aggressive overtures to win over the much beleaguered" African American community; "in short, pro-Tokyo sentiment was perceived as widespread among United States Negroes” (1). Executive Order 9066, signed by Franklin D. Roosevelt just months after the bombing of Pearl Harbor, resulted in the mass internment of more than 120,000 persons of Japanese descent living on the West Coast, two-thirds of them US-born citizens. In the midst of virulent anti-Japanese propaganda, a 1944 Negro Digest poll showed that when 
asked, “' 'Should negroes discriminate against Japanese?' 66 percent in the North and 53 percent in the South answered 'No' ”' (qtd. in Lye 1735).

This transnational confluence of the idea of ethno-racial solidarity between Japan, Japanese Americans, and African Americans resurfaces in Demby's final novel King Comus (2017). Demby worked on the novel for some twenty years, yet it remained in manuscript form at the time of his death in 2013, though he finished the text in 2007. The novel weaves together multiple, interrelated plotlines that span the course of centuries and continents-from the turn of the nineteenth-century, at the height of colonialism and chattel slavery, to the turn of the neo-imperial, neoliberal twenty-first century. One of its narrative settings takes place during World War II and follows the experiences of two African American soldiers: a semi-autobiographical character named "D." and Tillman, a descendent of the eponymous King Comus, an escaped slave and virtuoso musician. D. is a college-educated Northerner, while Tillman hails from Oklahoma, not far from their training camp.

As a companion piece of sorts to Horne's anecdote of Malcolm X's meeting with an army psychiatrist, early in King Comus, a white army psychiatrist attempts to recruit D. as his assistant on the basis of D.'s college coursework in psychology (23). In paternalistic language, the psychiatrist tells D.:

Those few of you who have achieved a university degree whatever its quality seem strangely uninterested in pursuing careers in the mental health sciences even though-both here and in Europe and eventually in both the Far East and the Near East-the mental health sciences will be the secret weapon so to speak in the what now appears inevitable restructuring of human society! (23)

The psychiatrist insists, "[Y]ou and I would be pioneers exploring the effects of this strangely racial war on your people who, in the opinion of many, and not only leftwing and right-wing radicals, would have every right to side with the enemy" (King Comus 23). In an attempt to elicit D.'s true sympathies, the psychiatrist cites leftist publications written by D. as a high school student, summarizing: "You insinuate that the war we are engaged in is less a war against Nazi Germany and Fascist Italy than a race war aimed at the ultimate subjugation of the colored peoples of the world" (24). He presses D., "What do you really think about all this? All this ideological confusion? For example, it's my understanding many of your people are secretly sympathetic to the Japanese Fascist cause"; in response, D. blurts out, "Only because the Japanese aren't white," to which the psychiatrist retorts, "Then I suppose you are one of those who consider this a war for white supremacy" (24). D. clarifies, "Not really. I personally believe this is a just war, that it's being fought to save the world for democracyI was referring to colored people all over the world who consider themselves unjustly oppressed, the colored masses who have been held down so long they consider the war a-" (25). The mention of the word "masses" elicits a triumphant response from the psychiatrist, who believes he has drawn out D.'s true allegiances (25). Much to the psychiatrist's chagrin and dismay, D. refuses the post he is offered-again, to surveil 
the effects of the war on African American troops-an offer that is predicated upon the Army's having surveilled D.'s juvenilia-in spite of the fact that it would afford him safety and relative privilege. Against this opportunity, D. consciously chooses to serve alongside his new friend, Tillman.

Inasmuch as the scene is a domestic one attuned to the secondary status of African Americans in the United States armed forces, it is, at the same time, a global scene, calling attention to the scope of global warfare and the destinies of the world's peoples being intertwined, as Wright surmises of the Afro-Asian Bandung Conference. With this direct commentary on the racist logics of United States state-sanctioned segregation and the implicit hypocrisy of the United States fighting oppression abroad, while enforcing subjugation at home, the novel narrates the experience of African Americans serving in World War II-a chapter that is largely missing from literary accounts of the period. Calling attention to wartime discourses regarding people of color around the world, Demby's novel makes subtle ties to the global liberation movements to come in the postwar years, a sentiment that would find collective political purchase at the Bandung Conference.

\section{Conclusion}

Among Carl Van Vechten's papers is a leaflet for the April 12, 1955 art opening of painter Umberto Maria Casotti’s Dipinti Inspirati Al Jazz, or Paintings Inspired by Jazz, at Rome's Galleria delle Carrozze. The leaflet, which Demby shared with Van Vechten, features images of two cubistic paintings by Casotti of black jazz musicians, as well as a short essay by Demby. Demby's essay is published side-by-side in the leaflet in Italian and English and is dated November 1953, Tokyo. In the short piece, Demby describes retreating into a Tokyo bar on a cold November night where, inside, a group of Japanese youth are listening with rapt attention to a Louis Armstrong record. As he walks home that night, he hears traditional samisen music blaring in the street. Demby posits, "Perhaps in jazz music and its cult around the world we have found a universal folk music which hints at the existence of a universal soul." This concept leads to his assessment of Casotti's jazz paintings:

\footnotetext{
A Negro did not paint these studies of jazz musicians: Casotti is no Negro. Yet had a Negro painted them one can easily imagine the lavish chauvinistic praise they would receive. But the artist deserves this praise anyway, for he has had the courage and sensitive understanding to burrow deep below the long-hardened crusts of national and racial culture to shed light on a strange world at once primitive, modern and disconcertingly prophetic.
}

This cosmopolitan analysis articulates a transnational human solidarity found in the arts and across media. Far from eliding difference, Demby's analysis prompts the viewer, listener, and reader to "burrow deep below the long-hardened crusts of 
national and racial culture." The following year, Demby received a letter from his friend, writer and librarian Arna Bontemps, informing him that two Casotti paintings were hopefully to remain at Fisk University. Carl Van Vechten, Bontemps, and Demby all shared ties with Fisk-these transnational affiliations led to Italian visual culture, possibly Casotti's works inspired by jazz, traveling to Nashville, Tennessee, on display at an historically black university, a compelling instance of cosmopolitan material culture.

Demby's decades of sustained work across genres and national borders in the Cold War period warrants our critical consideration. His having lived abroad for decades, perhaps, has led to his peripheral status in the African American literary canon. On the other hand, this very situatedness prompts us to read his writings from a global perspective-one attentive to the specificity of time, place, and lived experience, but cognizant of Demby's active efforts to find vocabularies to cut across traditional categorizations in search of horizontal, relational affiliations. It would seem that it was in this spirit that Demby wrote to his wife, Lucia Drudi, from Tokyo in November of 1953, "I suppose the real meaning of this trip for me was to complete an understanding of how people around the world are tied so closely together in their arts and views of life. I feel a strange sense of freedom, as if I am no longer bound by imagined laws and ways of thinking" (William Demby Papers). Demby's critical cosmopolitan writings orient us toward transnational and transcultural solidarities, even as they often dwell in language's gaps and misfires, demonstrating the differential, incomplete quality of experience in what Kwame Anthony Appiah aptly calls a world of "strangers" (xxi). In his discussion of Demby's The Catacombs, Werner Sollors “wonders whether perceptions like Demby's would have emerged in an American setting” (50). Likely, he implies, and I would affirm, they would not have, or at least not in the same fashion. With his writings' attention to global affinities and creative and political networks, Demby chronicled and gave voice to critical cosmopolitanisms and evolving histories of struggle against racism, sexism, and imperialism that continue to resonate with urgency in our present.

\section{Works Cited}

Appiah, Kwame Anthony. Cosmopolitanism: Ethics in a World of Strangers. Norton, 2006.

Bhabha, Homi K. "Spectral Sovereignty, Vernacular Cosmopolitans, and Cosmopolitan Memories." Robbins and Horta, pp. 141-152.

Carl Van Vechten Papers Relating to African American Arts and Letters, James Weldon Johnson Collection, MSS 89, Box 60, Folder “W. Demby." Yale Collection of American Literature, Beinecke Rare Book and Manuscript Library, Hartford, CT. Accessed 17 Dec. 2015.

Chandler, Nahum. "A Persistent Parallax: On the Writings of W. E. Burghardt Du Bois on Japan and China, 1936-1937.” CR: The New Centennial Review, vol. 12, no. 1, pp. 291-316.

Demby, William. “An American Negro Survives.” East Hampton Star, 2 Nov. 1996, pp. II-1, II-5-II.6. -.-. Beetlecreek. 1950. UP of Mississippi, 1998. 
--.. "From a Japanese Notebook." Botteghe Oscure, vol. 23, 1959, pp. 249-268.

--.. King Comus. Ishmael Reed Publishing, 2017.

--.. “Le Ondine Del Signor Mikimoto." Epoca, vol. 211, no. 17, 1954, pp. 46-49.

--.. "Ridono E Piangono Sotto La Maschera." Epoca, vol. 16, no. 204, 1954, pp. 28-34.

---. "Sacerdotosse Dell-Illusione." Epoca, vol. 15, no. 195, 1954, pp. 46-51.

--.. The Catacombs. 1965. Northeastern Library of Black Literature, 1991.

-.-. "The Geisha Girls of Ponto-cho." Harper's, no. 209, Dec. 1954, pp. 41-47.

--.. "The Traveller." ca. 1956, From a Japanese Notebook, The William Demby Papers. Unpublished manuscript.

---. The William Demby Papers at the Villa Podernovo, Tuscany, Italy.

---. "They Surely Can't Stop Us Now." Reporter, no. 14, 5 Apr. 1956, pp. 18-21.

Haar, Francis. Francis Haar: A Lifetime of Images. Edited by Tom Haar, U of Hawaii P, 2001.

Hollinger, David. "Pluralism, Cosmopolitanism, and the Diversification of Diversity." Postethnic America: Beyond Multiculturalism, Basic Books, 2000, pp. 79-104.

Horne, Gerald. Introduction. Facing the Rising Sun: African Americans, Japan, and the Rise of Afro-Asian Solidarity, by Horne, New York UP, 2018, pp. 1-29.

Horta, Paulo Lemos. “Cosmopolitan Prejudice.” Robbins and Horta, pp. 153-170.

Luczak, Ewa. "From Skepticism to New Humanisms or When Europe and Africa Converse in Rome: William Demby's The Catacombs." How Their Living Outside America Affected Five African American Authors: Toward a Theory of Expatriate Literature, The Edwin Mellen P, 2010, pp. 113-147.

Lye, Colleen. "The Afro-Asian Analogy.” PMLA, vol. 123, no. 5, 2008, pp. 1732-1736.

MacLeish, Archibald. Introduction. Botteghe Oscure Index: 1949-1960, edited by George Garrett, Wesleyan UP, 1964, pp. ix-xii.

Micconi, Giovanna. "Ghosts of History: An Interview with William Demby." Amerikastudien / American Studies, vol.56, no. 1, 2011, pp. 123-139.

Mullen, Bill. Afro-Orientalism. U of Minnesota P, 2004.

Onishi, Yuichiro. Introduction. Transpacific Antiracism: Afro-Asian Solidarity in 20th-Century Black America, Japan, and Okinawa, by Onishi, New York UP, 2017, pp. 1-15.

Robbins, Bruce, and Paulo Lemos Horta, editors. Cosmopolitanisms. New York UP, 2017.

Said, Edward. Introduction. Orientalism, by Said, Vintage, 1979, pp. 1-28.

Sollors, Werner. "Not on Native Grounds." Moravian Journal of Literature and Film, vol. 1, no. 1, Fall 2009, pp. 49-53.

Saunders, Frances Stonor. The Cultural Cold War: The CIA and the World of Arts and Letters. The New P, 2012.

Yamamoto, Traise. “'As Natural as the Partnership of Sun and Moon': Western Masculinity, Japanese Women and the Feminization of Japan." Masking Selves, Making Subjects: Japanese American Women, Identity, and the Body, by Yamamoto, U of California P, 1999, pp. 9-61.

Wright, Richard. The Color Curtain. 1956. UP of Mississippi, 1994. 